\title{
Impact of Drought Stress during Germination on Antioxidant Capacities and Antioxidant Enzymes Activities of Madura Local Maize (Zea mays) Seeds
}

\author{
Agnes Rezkyta Herwang Dani' ${ }^{1}$, Tri Agus Siswoyo, ${ }^{1,2}$ \\ ${ }^{1}$ Graduate School of Biotechnology, Jember University, Jember, Indonesia \\ ${ }^{2}$ The Center of Excellence on Crop Industrial Biotechnology, University of Jember, Jember, Indonesia \\ Email: triagus.faperta@unej.ac.id, siswoyo.triagus@gmail.com
}

How to cite this paper: Dani, A.R.H. and Siswoyo, T.A. (2019) Impact of Drought Stress during Germination on Antioxidant Capacities and Antioxidant Enzymes Activities of Madura Local Maize (Zea mays) Seeds. Agricultural Sciences, 10, 1506-1516. https://doi.org/10.4236/as.2019.1011111

Received: October 31, 2019

Accepted: November 26, 2019

Published: November 29, 2019

Copyright $\odot 2020$ by author(s) and Scientific Research Publishing Inc. This work is licensed under the Creative Commons Attribution-NonCommercial International License (CC BY-NC 4.0). http://creativecommons.org/licenses/by-nc/4.0/

\begin{abstract}
The effect of various polyethylene glycol (PEG) concentrations to induced drought stress on the antioxidant capacities and antioxidant enzyme activities was investigated on Madura local maize during germination. Seed samples were treated under $5 \%, 10 \%$, and $15 \%$ of PEG for 6 days. The changes in the antioxidant capacities such as 2,2'-azino-bis-3-ethylbenzthiazoline-6-sulphonic acid (ABTS) and hydroxyl radical scavenging; antioxidant enzyme activities including catalase (CAT) and ascorbate peroxidase (APX) and gene expression were observed during seeds germination. The result showed the antioxidants capacities and enzyme activities exhibited a significantly higher level in drought-treated. The most effective level of drought stress to elevate the capabilities and enzyme activity of antioxidant as well as it gene expression was observed at 15\% PEG, whereas ABTS scavenging activity was increased $20 \%$ over the control, hydroxyl scavenging activity up to $14 \%$, CAT and APX activity increased 4 - 5 times over the control. Along with the presence of antioxidant mechanisms, including the capacities and activities of different types of $\mathrm{ABTS}^{+}$, hydroxyl, CAT, and APX might play important roles during the germination phase and be able to manage reactive oxygen species to the normal level under stress condition.
\end{abstract}

\section{Keywords}

Drought, Antioxidant, Germination, Maize, Polyethylene-Glycol 


\section{Introduction}

One of the major environmental factors of plant growth and productivity is drought stress. The plant that growth under drought stress can have an adverse effect on physiological, biochemical, and morphological. It is involved in metabolic responses such as signaling, physiological regulation, and defense responses [1] [2] [3]. The stresses can reduce the percentage of germination and delays the inception of seed germination [4] [5]. The inhibition of plant and root growth is the first growth response in plants related to drought stress, to reduce transpiration for water conservation [6]. Generally, the consequence of these stress is formed of reactive oxygen species (ROS) as a result of one, two, or three donor electron, which formed superoxide $\left(\mathrm{O}_{2}{ }^{\circ}\right)$, peroxide hydrogen $\left(\mathrm{H}_{2} \mathrm{O}_{2}\right)$, and hydroxyl radical $\left(\mathrm{OH}^{\circ}\right)$ [5] [7] [8]. The rapid metabolic responses help the cells to manage stress, restore chemical, and imbalance an energetic and prevent the cells from damage [9] [10] [11].

One defense mechanism in the plant is the antioxidant defense system, which includes the antioxidant enzymes and the non-enzyme antioxidant [12]. Enzymatic antioxidants usually consider as the most effective defense. It directly scavenges the ROS or managing the non-enzymatic defense as indirect protection [8] [11] [12]. Common plant antioxidant enzymes such as peroxidase, superoxide dismutase, ascorbate peroxidase, and catalase can detoxify the $\mathrm{O}_{2}{ }^{\circ}$ and $\mathrm{H}_{2} \mathrm{O}_{2}$ to prevent oxidative damage. Ascorbate is used by APX as a donor to convert $\mathrm{H}_{2} \mathrm{O}_{2}$ to water, and catalase dissolved $\mathrm{H}_{2} \mathrm{O}_{2}$ into water and oxygen [7] [12]. Various related research indicates that the capacities and activities of antioxidant enzymes are correlated with plant resistance to abiotic stress, including drought stress [5] [8] [12] [13] [14].

Maize (Zea mays L.) is the third important crop commodity in the world following wheat and rice [14] [15]. It is a cosmopolitan plant with a wide-grown spectrum of climatic and soil conditions [11] [15]. Madura maize is one of the indigenous maize from Indonesia. It is known as maize that can grow in low water level, acid, and high-temperature conditions, but has not been studied well. On the side, as an important crop commodity, maize should have a good seed adaptation. Base on seed physiology, seed germination is a critical phase in seedling establishment, determining the success of crop production and more sensitive to stress than another stage [9]. It is important to note that maize is a moderate sensitive plant to the salinity [14] and drought stress that can inhibit the growth [2] [16]. However, the effect of drought stress and the response of antioxidant defense during the earliest germination has been reported well on another commodity, such as rice [9] [17], wheat [8], Sunflower [6] [18] and alfalfa [12].

In the present study, for a better understanding of maize adaptability under drought stress during germination, we investigated the defense against the stress of Madura local maize under varieties concentration of PEG by evaluating the maize growth, antioxidant capacities, and antioxidant enzyme activities. 


\section{Materials and Methods}

\subsection{Plant Material and Culture Condition}

Seeds of Madura local maize were stocked in Center Laboratory for Development of Advanced Sciences and Technology, University of Jember. Seeds were surface-sterilized with $1 \%$ sodium hypochlorite solution for 10 minutes, thoroughly rinse 7 - 8 times with sterile distilled water, and imbibed for $5 \mathrm{hr}$ in the treatment solution. After the imbibition, 15 seeds were planted into the tray with a treatment solution and a wet towel.

\subsection{PEG Treatment}

Drought stress was initiated by treated the seeds with $5 \%, 10 \%$, and $15 \%(\mathrm{~W} / \mathrm{V})$ of PEG, then maintained under these conditions for 6 days. Control seeds were kept in distilled water without PEG. Samples were collected every 2 days during treatment, measured the root length, and kept the samples on $-20^{\circ} \mathrm{C}$.

\subsection{Enzyme Extraction and Protein Determination}

The frozen seeds were mashed into powder and extract with $0.5 \mathrm{mM}$ phosphate buffer $(\mathrm{pH} 7.4)(1: 3 / \mathrm{W}: \mathrm{V})$. The homogenate solution was centrifuged at 10.000 rpm for 15 minutes at $4^{\circ} \mathrm{C}$, and the supernatant was used for protein and antioxidant enzyme assays. Preparation for the extraction was carried out at $4^{\circ} \mathrm{C}$. The total concentration of soluble protein was determined according to the Bradford method [19] using bovine serum albumin (BSA) as a standard.

\subsection{Assay of Antioxidant Capacity}

The antioxidant capacity was performed based on the 2,2'-azino-bis-3-ethylbenzthiazoline-6-sulphonic acid (ABTS) radical scavenging activity. The assay of ABTS radical scavenging activity was conducted through the method as described by literature [20]. The ABTS was generated by the reaction of $7 \mathrm{mM}$ ABTS aqueous solution with $2.45 \mathrm{mM}$ potassium persulfate and incubated in the dark for $12-16 \mathrm{hr}$. Prior to the assay, the ABTS solution was diluted with $0.2 \mathrm{M}$ sodium phosphate-buffer saline ( $\mathrm{pH} 7.4$ ) to absorbance $0.70-0.75$ at $734 \mathrm{~nm}$. The assay contained $950 \mu \mathrm{l}$ of ABTS solution with $30 \mu \mathrm{l} 0.2 \mathrm{M}$ sodium phosphate-buffer saline and $70 \mu \mathrm{g}$ protein extracts. The absorbance was measured at $734 \mathrm{~nm}$. The antioxidant activity was calculated by the following Equation (1):

$$
\left(\frac{A c-A s}{A c}\right) \times 100 \%=A B T S \text { activity }(\%)
$$

where,Ac: absorbance control and As: absorbance sample. Hydroxyl radical scavenging activity was analyzed base on spectrophotometric, according to literature [21]. $75 \mu \mathrm{g}$ protein extract was introduced with $25 \mu \mathrm{l} 28 \mathrm{mM}$ 2-deoxy-dribose in $20 \mathrm{mM} \mathrm{KH}_{2} \mathrm{PO}_{4}$ (pH 7.4), $100 \mu \mathrm{l} 1 \mathrm{mM}$ EDTA, $5 \mu \mathrm{l} 10 \mathrm{mM} \mathrm{FeCl}, 10 \mu \mathrm{l}$ $1 \mathrm{mM} \mathrm{H}_{2} \mathrm{O}_{2}, 100 \mu \mathrm{l} 1 \mathrm{mM}$ ascorbic acid, $260 \mu \mathrm{l} 20 \mathrm{mM}$ phosphate buffer $\mathrm{pH} 7.4$ and incubated at $37^{\circ} \mathrm{C}$ for $1 \mathrm{hr}$. After incubation, the solution was then added 
with $250 \mu \mathrm{l} 1 \%$ TBA and $250 \mu \mathrm{l} 2.8 \%$ TCA then re-incubated for $30 \mathrm{~min}$ at $85^{\circ} \mathrm{C}$. The absorbance was measured at $532 \mathrm{~nm}$ using a spectrophotometer.

\subsection{Determination of Antioxidant Activity}

Catalase (CAT) activity was determined based on spectrophotometric, according to literature [22] by observed the reducing of $\mathrm{H}_{2} \mathrm{O}_{2}$ at wavelength $240 \mathrm{~nm}$ for 3 minutes $\left(=43.6 \mathrm{M}^{-1} \cdot \mathrm{cm}^{-1}\right)$. The total mixture $(1 \mathrm{ml})$ contained $20 \mathrm{mM}$ phosphate buffer ( $\mathrm{pH} 7.4$ ) and $20 \mathrm{mM} \mathrm{H}_{2} \mathrm{O}_{2}$. The reaction was initiated by adding $75 \mu \mathrm{g}$ protein seed extract and measure for 3 minutes at $240 \mathrm{~nm}$. The Ascorbate Peroxidase (APX) activity was assayed base on the decrease in absorbance at 290 $\mathrm{nm}$ [7] using ascorbic acid as a substrate. The oxidation of ascorbate was initiated by $\mathrm{H}_{2} \mathrm{O}_{2}$, and decreased was observed for 3 minutes $\left(=2.8 \mathrm{mM}^{-1} \cdot \mathrm{cm}^{-1}\right)$. The reaction mixture contained $20 \mathrm{mM}$ phosphate buffer ( $\mathrm{pH} 7.4$ ), ascorbate acid, $0.06 \%$ of $\mathrm{H}_{2} \mathrm{O}_{2}$, and $75 \mu \mathrm{g}$ protein extracted.

\subsection{Analysis of Gene Expression}

The RNA was isolated from $0.1 \mathrm{~g}$ leaf samples, following the protocols from total RNA plant isolation kit (NucleoSpin ${ }^{\circledast}$ RNA Plant, Machenery-Nagel). Total elution was $40 \mu \mathrm{l}$ and the concentration of RNA was measured at 260 and $280 \mathrm{~nm}$ using nano-drop spectrophotometer (GE Nanovue Plus). For the cDNA synthesis, 900 ng RNA was dissolved in $20 \mu$ RT-Premix (Bioneer Hyper Script RT) and used as template for polymerase chain reaction. Polymerase chain reaction (PCR) condition was conducted at $94^{\circ} \mathrm{C}$ for $30 \mathrm{sec}, 58^{\circ} \mathrm{C}$ for $30 \mathrm{sec}, 72^{\circ} \mathrm{C}$ for 30 sec, and $72^{\circ} \mathrm{C}$ for $7 \mathrm{~min}$ as final extension. The sequence primer of used for APX2 were CCATGGTGA-AGAAGAGTTACCCGGAAGT (forward) and TCTGAGATTACTCCTTGTCAGCAAACCCGA (reverse) and CAT were CCCATTCTACACCACAAA (forward) and ACCCTTAGCACTGATTCC (reverse). The primer used for reference gene was $\beta$-tubulin,

ATCGATTCCGTTCTCGATGT (forward) and ATCCAGTTCCTCCTCCCAAC (reverse). The PCR product was visualized in $1.5 \%$ agarose gel.

\subsection{Statistical Analysis}

All measurements were subjected to analysis using the SPSS statistical program. Duncan's multiple range test was done at $5 \%$ of significant differences $(p \leq 0.05)$.

\section{Results and Discussion}

\subsection{Changes in Maize Growth under Drought Stress}

Maize growth was affected by drought conditions, under the higher concentration of PEG, root number, elongation, and growth were increased (Figure 1). For $15 \%$ of PEG concentration, increased up to $37 \%, 5.7 \mathrm{~cm}$ under normal condition, and $7.8 \mathrm{~cm}$ under $15 \%$ of PEG treatment, followed by $10 \%$ of PEG treatment $(6.5 \mathrm{~cm})$ and $5 \%$ of PEG treatment $(6.2 \mathrm{~cm})$. The result indicated that 


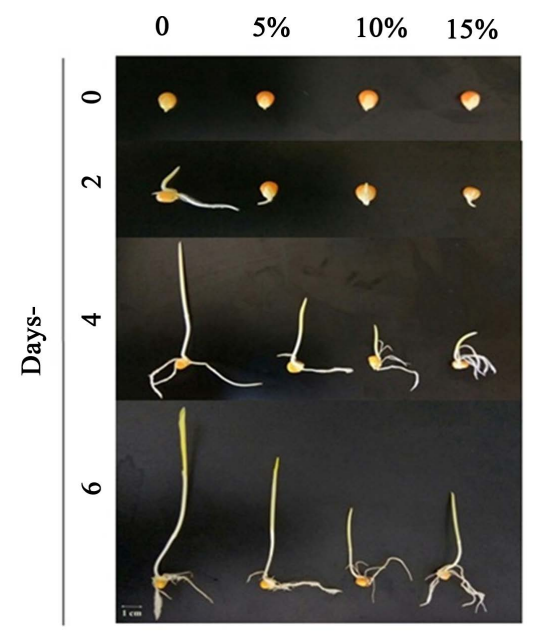

Figure 1. Effect of PEG concentration on seeds germination at different time periods.

drought stress stimulates roots to lengthen and increased root number, to adapt against the stress. A similar result is reported by literature [23] root length were increased during the drought stress compared to a well-watered plant.

The result showed a positive correlation between the increase of root length with increasing PEG concentration. Roots are one of a defense mechanism in the plant, and the longer root might help a plant to survive by a better absorption, thus supported the biomass accumulation under drought stress [2] [4] [6] [10] [15]. In literature [24] reported in triticale, PEG increase the root length in low concentration, but it stops at the osmotic potential in high concentration. The drought had a greater inhibition effect on root length, and it would decrease with the increase of drought level [4] [9] [17] [25].

\subsection{Antioxidant Capacities Activities under Drought Stress}

To determine the antioxidant responses of maize under drought stress, we observed the antioxidant capacities for 6 days after imbibition. ABTS assay showed the antioxidant scavenging activity was increased during the treatment with the increase of stress level and the age of plants. Maize had significantly more activity of antioxidants under the high level of drought stress over the control (55.6\%), whereas 15\% PEG (71.27\%). ABTS activity increase with expanding of stress level and the age of plants, in drought (Figure 2(a)). Its activity, do not show significant difference during the early germination on control and 5\% treatment, increased was showed on $10 \%$ and $15 \%$ treatment. After 3 days enhancement occurred in all treatment, $15 \%$ showed a higher increasing followed by $10 \%$ and $5 \%$. Our result was linear with literature [25] that reported ABTS content of tartary buckwheat were not improved significantly during the first 2 days of germination and gave different results after the 7 days treatment. It had a powerful scavenging effect on free radicals.

Hydroxyl scavenging assay has shown a similar result, and it increases with the increase of stress level compared to the control (Figure 2(b)). After treated 


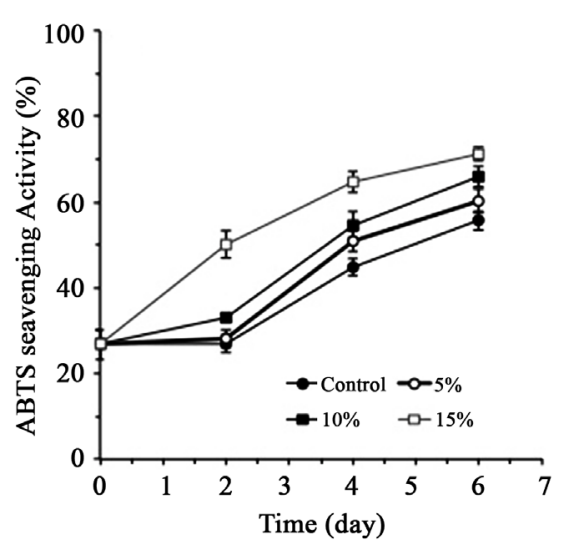

(a)

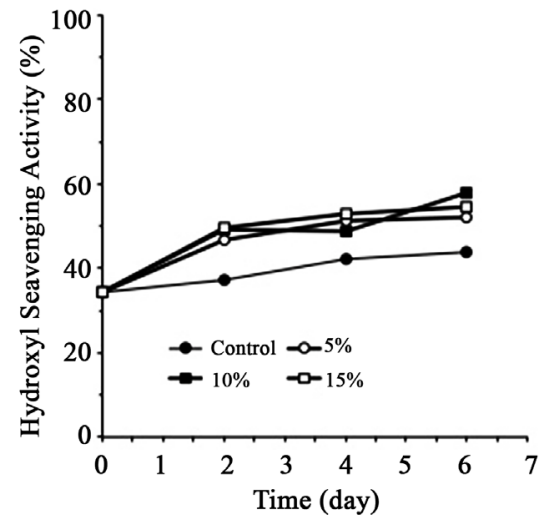

(b)

Figure 2. ABTS (a) and hydroxyl scavenging (b) activities of seed germination of seed germination under PEG concentration at different time periods.

for 6 days by 5\%,10\%, and 15\% concentration of PEG, the enhancement was $47 \%, 64 \%$ and $55 \%$, respectively. Sprout that treated by $10 \%$ PEG showed higher hydroxyl scavenging, but were not significantly different with $15 \%$ PEG treatment. It is assumed as a result of an accumulation from antioxidative compounds, such as antioxidant enzymes that contribute to scavenging free radicals.

\subsection{Antioxidant Enzyme Activities under Drought Stress}

The activity of APX increased at all the treatment in PEG stress. Maize had significantly more activity of APX under the high level of drought stress over the control (55.2\%), whereas 15\% of PEG (71.27\%). Its activity increase with the increase in stress level and the age of plants (Figure 3(a)). At 6 days APX activity 5 - 7 times higher than 0 days and 2 - 4 times than control. Our result was in line with the finding of literature [8] in maize, and another plant such as rice [4] [12] [26], wheat [8], melinjo [7], and alfalfa [12].

CAT has the same trend as the APX, and drought stress increases the CAT level during the early stage of germination. CAT was increased with the increase of stress levels. On the last day of treatment, CAT activity at 15\% PEG increases 24 times than the first, whereas $10 \%$ increase 6 times, $5 \%$ increase 8 times and 7 times for the control (Figure 3(b)). Under the high level of stress, CAT activity drastically expands as in literature [27] reported that is a strategy for improving the tolerance against stress. Our result was similar to the literature [13] and [8] in maize, and another plant such as rice [4] [11] [12] [26] [28], wheat [8], melinjo [7], alfalfa [12] and sunflower [14].

Enzymatic antioxidants, such as APX and CAT, are an important plant defense mechanism against stress [8] [12] [28]. APX and CAT, which can detoxification $\mathrm{H}_{2} \mathrm{O}_{2}$, play a key role in scavenging free radicals in drought stress [12] [28]. Maize has more amounts of ascorbic acid and glutathione, liner to its higher activity of APX, and glutathione reductase [8]. CAT reducing $\mathrm{H}_{2} \mathrm{O}_{2}$ by dissolving it directly into water and oxygen. Therefore, CAT has a high reaction 


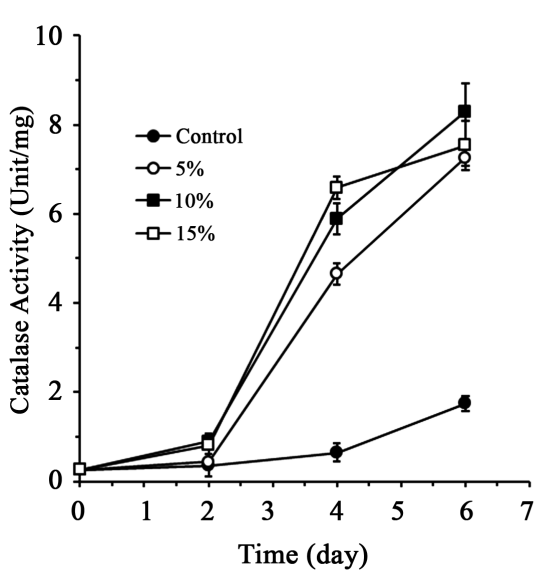

(a)

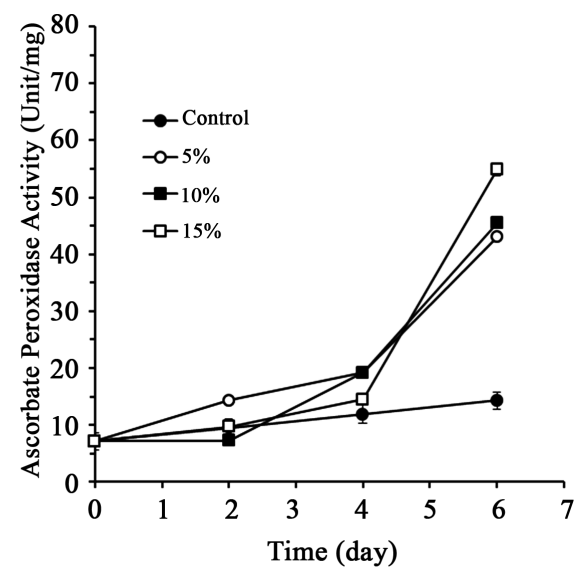

(b)

Figure 3. Catalase (a) and ascorbate peroxidase (b) activities of seed germination under PEG concentration at different time periods.

rate and does not need reducing power, but also a low affinity of $\mathrm{H}_{2} \mathrm{O}_{2}$ and causing it only removed the high concentration of $\mathrm{H}_{2} \mathrm{O}_{2}$ [12]. The result indicated that APX and CAT levels in maize under drought treatment up to $15 \%$ PEG were able to managed ROS at a normal level.

\subsection{APX and CAT Gene Expression}

Observation on the gene expression level of APX and CAT showed a similar result with enzyme activities, and the gene expression was increased during treatment. As shown in Figure 4, the thicker band after 2 and 6 days of treatment compared to the control indicated that APX and CAT gene expression was increased.

Stress affects the expression of the APX gene in the early stage of germination (11 days). After 6 weeks, it has no significant effect [29] [30]. In literature [31] was reported that some APX gene is increased under stress condition on rice. A similar increased also observed in transgenic tobacco [32] [33] [34] and barley [35]. CAT gene expression is also affected by the stress condition, and it significantly increased after 2 days. A Similar result in Ipomea batatas was reported by literature [30] CAT gene expression is increased significantly after 2 days and decreased on the 20 days. The same finding is observed in other plants such as Pitaya [36], rice [37], Medicago falcet, and Cleome spinosa.

\section{Conclusion}

During germination, there are differences in morphological, biochemical, antioxidant capacities, and antioxidant enzyme activities of maize seeds under stress and normal condition. Seeds portability was increased during the germination under drought stress conditions. Along with the presence of antioxidant mechanisms, including the capacities and activities of different types of ABTS, hydroxyl, CAT, and APX might play important roles during the germination 


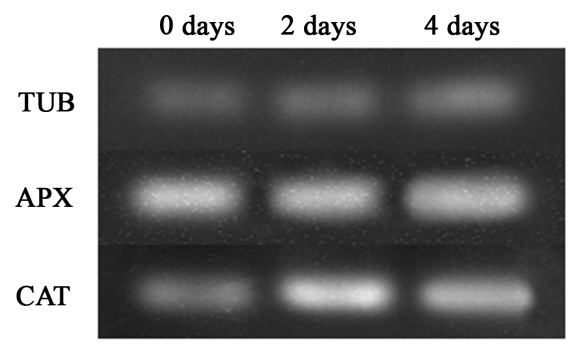

Figure 4. Catalase and ascorbate peroxidase gene expression under 15\% PEG concentration at different time periods.

phase. We concluded that the germination seeds could use as natural antioxidant agents, and drought could induce the improvement of antioxidant level, it has the possibility of employing them for therapeutic purposes.

\section{Funding}

This research work was supported by the IsDB 4-1 Project, University of Jember Indonesia.

\section{Conflicts of Interest}

The authors declare no conflicts of interest regarding the publication of this paper.

\section{References}

[1] Aliu, S., Rusinovci, I., Fetahu, S., Gashi, B., Simeonovska, E. and Rozman, L. (2015) The Effect of Salt Stress on Germination of Maize (Zea mays L.) Seeds and Photosynthetic Pigments. Acta Agriculturae Slovenica, 105, 85-94. https://doi.org/10.14720/aas.2015.105.1.09

[2] Bashir, N., Mahmood, S., Zafar, Z.U., Athar H.R., Manzoor, H. and Rasul, S. (2016) Is Drought Tolerance in Maize (Zea mays L.) Cultivars at the Juvenile Stage Maintained at the Reproductive Stage. Pakistan Journal of Botany, 48, 1385-1392.

[3] Liang, W., Ma, X., Wen, P. and Liu, L. (2018) Plant Salt-Tolerance Mechanism: A Review. Biochemical and Biophysical Research Communication, 495, 286-291. https://doi.org/10.1016/j.bbrc.2017.11.043

[4] Alpay, B., Temel, G., Ogus, B. and Hakan, U. (2015) Response of Rice (Oryza sativa L.) to Salinity Stress at Germination and Early Seedling Stages. Pakistan Journal of Agricultural Sciences, 52, 453-459.

[5] Farooq, M., Wahid, A., Kobayashi, N., Fujita, D. and Basra, S.M.A. (2009) Plant Drought Stress: Effects, Mechanisms and Management. Agronomy for Sustainable Development, 29, 185-212. https://doi.org/10.1051/agro:2008021

[6] Saeed, R. and Hafeez, A.S. (2007) Effect of Varied Water Regimes on Root Length, Dry Matter Partitioning and Endogenous Plant Growth Regulator in Sunflower (Helianthus annus L.). Journal of Plant Interaction, 2, 41-51. https://doi.org/10.1080/17429140701422512

[7] Arum, L.S., Supriyadi, A., Novianti, E., Fanata, W.I.D. and Siswoyo, T.A. (2018) Drought Stress-Induced the Expression Level of Ascorbate Peroxidase in the LateStage Seedling of Melinjo (Gnetum gnemon L). International Journal of Agriculture 
\& Biology, 20, 1303-1308.

[8] Nayyar, H. and Gupta, D. (2006) Differential Sensitivity of C3 and C4 Plants to Water Deficit Stress: Association with Oxidative Stress and Antioxidants. Environmetal and Experimental Botany, 58, 106-113. https://doi.org/10.1016/j.envexpbot.2005.06.021

[9] Hakim, M.A., Juraimi, A.S., Begum, M., Hanafi, M.M., Ismail, M.R. and Selamat, A. (2010) Effect of Salt Stress on Germination and Early Seedling Growth of Rice (Oryza sativa L.). African Journal of Biotechnology, 9, 1911-1918. https://doi.org/10.5897/AJB09.1526

[10] Shobbar, M.S., Azhari, O. and Shobbar, Z.S. (2012) Comparative Analysis of Some Physiological Responses of Rice Seedling to Cold, Salt and Drought Stresses. Journal of Plant Nutrition, 35, 1037-1052. https://doi.org/10.1080/01904167.2012.671407

[11] Velaquez, S.F. and Hernandez, V.E.B. (2013) Abiotic Stress in Plant and Metabolic Response in Plant Responses and Application in Agriculture. IntechOpen Limited, London, 25-48.

[12] Wang, W.B., Kim, Y.H., Lee, H.S., Kim, K.Y., Deng, X.P. and Kwak, S.S. (2009) Analysis of Antioxidant Enzyme Activity During Germination of Alfalfa Under Salt and Drought Stresses. Plant Physiology and Biochemistry, 47, 570-577. https://doi.org/10.1016/j.plaphy.2009.02.009

[13] Farooq, M., Hussain, M., Wakeel, A. and Siddique, K.H.M. (2015) Salt Stress in Maize: Effect, Resistance Mechanism and Management. A Review. Agronomy for Sustainable Development, 35, 461-481. https://doi.org/10.1007/s13593-015-0287-0

[14] Gonzales, K.R., Erdei, L. and Lips, S.H. (2002) The Activity of Antioxidant Enzymes in Maize and Sunflower Seedling as Affected by Salinity and Different Nitrogen Sources. Plant Science, 162, 923-930. https://doi.org/10.1016/S0168-9452(02)00040-7

[15] Partheeban, C., Chandrasekhar, C.N., Ravikesavan, R. and Gnanam, R. (2017) Effect of PEG Induces Drought Stress on Seed Germination and Seedling Character of Maize (Zea mays L) Genotypes. International Journal of Current Microbiology and Applied Sciences, 6, 1095-1104. https://doi.org/10.20546/ijcmas.2017.605.119

[16] Khodarahmpour, Z. (2011) Effect of Drought Stress Induced by Polyethylene Glycol (PEG) on Germination Indices in Corn (Zea mays L.) Hybrids. African Journal of Biotechnology, 10, 18222-18227. https://doi.org/10.5897/AJB11.2639

[17] Jamil, M. and Rha, E.S. (2007) Response of Transgenic Rice at Germination and Early Seedling Growth under Salt Stress. Pakistan Journal of Biological Sciences, 10, 4303-4306. https://doi.org/10.3923/pjbs.2007.4303.4306

[18] Markuji, K.A., Kovacevic, J. and Viljevac, V. (2016) Impact of Abiotic Stress on Photosynthetic Efficiency and Leaf Temperature in Sunflower. Poljoprivreda, 22, 17-22. https://doi.org/10.18047/poljo.22.2.3

[19] Bradford, M.M. (1976) A Rapid and Sensitive Method for the Quantitation of Microgram Quantities of Protein Utilizing The Principle of Protein-Dye Binding. Analytical Biochemistry, 72, 248-254. https://doi.org/10.1016/0003-2697(76)90527-3

[20] Re, N.P., Proteggente, A., Pannala, A., Yang, M. and Rice-Evans, C. (1991) Antioxidant Activity Applying an Improved ABTS Radical Cation Decolorization Assay. Free Radical Biology and Medicine, 26, 1231-1237. https://doi.org/10.1016/S0891-5849(98)00315-3

[21] Halliwell, B., Gutteridge, J.M.C. and Arouma, O.I. (1987) The Deoxyribose Method: 
A Simple Test Tube Assay for the Determination of Rate Constants for Reactions of Hydroxyl Radicals. Analytical Biochemistry, 165, 215-219. https://doi.org/10.1016/0003-2697(87)90222-3

[22] Aebi, H. (1984) Catalase In- Vitro. Methods in Enzymology, 105, 121-126. https://doi.org/10.1016/S0076-6879(84)05016-3

[23] Rauf, S. and Sadaqat, H.A. (2007) Effects of Varied Water Regimes on Root Length, Dry Matter Partitioning and Endogenous Plant Growth Regulators In Sunflower (Helianthus annuus L.). Journal of Plant Interactions, 2, 41-51. https://doi.org/10.1080/17429140701422512

[24] Zhou, X., Hao, T., Zhou, Y., Tang, W., Xiao, Y., Meng, X. and Fang, X. (2015) Relationships between Antioxidants Compounds and Antioxidant Activities of Tartary Buckwheat during Germination. Journal of Food Science and Technology, 52, 24582463. https://doi.org/10.1007/s13197-014-1290-1

[25] Nizam, I. (2011) Effect of Salinity Stress on Water Uptake, Germination and Early Seedling Growth of Perennial Ryegrass. African Journal of Biotechnology, 10, 10418 10424. https://doi.org/10.5897/AJB11.1243

[26] Shahandeh, S., Imani, A.A. and Shahbazi, H. (2013) Evaluation of the Relation of Antioxidant Enzyme Activity with Drought Tolerance in Vegetative and Reproductive Growth Stages. Annals of Biological Research, 4, 152-157.

[27] Vaidyanathan, H., Sivakumar, P., Chakrabarty, R. and Thomas, G. (2003) Scavenging of Reactive Oxygen Species in NaCl-Stressed Rice (Oryza sativa L.) - Differential Response in Salt-Tolerant and Sensitive Varieties. Plant Science, 165, 1411-1418. https://doi.org/10.1016/j.plantsci.2003.08.005

[28] Yahubi, M., Nematzadeh, G., Pirdashti, H., Modarresi, M. and Motaghian, A. (2014) The Effects of Salinity on Antioxidant Enzyme Activity in The Leave of Two Contrast Rice (Oryza Sativa L.) Cultivars. International Journal of Bioscience, 4, 116-125. https://doi.org/10.12692/ijb/4.11.116-125

[29] Menedez-Benevente, L., Texeira, F.K., Kamei, C.L.A. and Margis-Pinheiro, M. (2004) Salt Stress Induces Altered Expression of Gene Encoding Antioxidant Enzymes in Seedling of a Brazilian Indica Rice (Oryza sativa L.). Plant Science, 166, 323-331. https://doi.org/10.1016/j.plantsci.2003.10.001

[30] Yong, B., Xiaoyan, W., Pan, X., Zheng, H.Y., Fei, X.T., Hong, Z.X., Ma, Q.Q., Miao, Y.Z., Yuan, X.H., Jiang, Y.S. and Shao, H.H. (2017) Isolation and Abiotic Stress Resistance Analyses of Catalase Gene From Ipomea Batatas (L.) Lam. BioMed Research International, 2017, Article ID: 6847532. https://doi.org/10.1155/2017/6847532

[31] Texeira, F.K., Menedez-Benevente, L., Margis, R. and Margis-Pinheiro, M. (2004) Analysis of Molecular Evolutionary History of Ascorbate Peroxidase Gene Family: Interferences from the Rice Genome. Journal of Molecular Evolution, 59, 761-770. https://doi.org/10.1007/s00239-004-2666-Z

[32] Badawi, G.H., Kawano, N., Yamauchi, Y., Shimada, E., Sasaki, R., Kubo, A. and Tanaka, K. (2004) Over-Expression of Ascorbate Peroxidase in Tobacco Chloroplast Enhances the Tolerance to Salt Stress and Water Deficit. Physiologia Plantarum, 121, 231-238. https://doi.org/10.1111/j.0031-9317.2004.00308.x

[33] Sun, W.H., Duan, M., Li, F., Shu, D.F., Yang, S. and Meng, Q.W. (2010) Over-Expression of $S t A P X$ in Tobacco Improves Seed Germination and Increases Early Seedling Tolerance to Salinity and Osmotic Stress. Plant Cell Reports, 29, 917-926. https://doi.org/10.1007/s00299-010-0878-9 
[34] Lee, Y.P., Kim, S.H., Bang, J.W., Lee, H.S., Kwak, S.S. and Kwon, S.Y. (2007) Enhanced Tolerance to Oxidative Stress in Transgenic Tobacco Plants Expressing Three Antioxidant Enzymes in Chloroplast. Plant Cell Reports, 26, 591-598. https://doi.org/10.1007/s00299-006-0253-Z

[35] Shi, W.M., Muramoto, Y., Ueda, A. and Takabe, T. (2001) Cloning of Peroximal Ascorbate Peroxidase Gene from Barley and Enhanced Thermotolerance by OverExpressing in Arabidopsis thaliana. Gene, 273, 23-27. https://doi.org/10.1016/S0378-1119(01)00566-2

[36] Nie, Q., Gao, G.L., Fan, Q.J., Qiao, G., Wen, X.P., Liu, T., Peng, Z.J. and Cai, Y.Q. (2015) Isolation and Characterization of A Catalase Gene "HuCAT3" from Pitaya (Hylocereus undatus) and Its Expression Under Abiotic Stress. Gene, 563, 63-71. https://doi.org/10.1016/j.gene.2015.03.007

[37] Vighi, I.L., Benitez, L.C., Amaral, M.N., Aurel, P.A., Moraes, G.P., Rodrigues, G.S., da Maia, L.C., Pinto, L.S. and Braga, E.J. (2016) Changes in Gene Expression and Catalase Activity in Oryza sativa L. Under Abiotic Stress. Genetics and Molecular Research, 15, 1-15. 